An Updateon Jobs for

Doctorates in Mathematics

Education at Institutions

of Higher Education in the

United States

\author{
Robert Reys, Barbara Reys, and Anne Estapa
}

For more than two decades, institutions of higher education have reported shortages for doctorates in mathematics education; i.e., there have been more jobs announced for doctorates in mathematics education than qualified people to fill them [1], [2], [3]. During the last five years there has been a major downturn in the national economy in the United States. The bleak economic conditions have resulted in declines in state revenues, which have created decreases in state expenditures. Consequently, nearly all of the state legislatures have reduced funding for institutions of higher education.

Robert Reys is Curators' Professor Emeritus of mathematics education in the College of Education at the University of Missouri. His email address is reysr@mi ssouri . edu.

Barbara Reys is Curators' Professor and Lois Knowles Faculty Fellow in the College of Education at the University of Missouri. Her email address is reysb@mi ssouri . edu.

Anne Estapa is assistant professor of mathematics education at Iowa State University. Her email address is aestapa@iastate.edu.

Members of the Editorial Board for Doceamus are: David Bressoud, Roger Howe, Karen King, William McCallum, and Mark Saul.

DOI: http://dx.doi.org/10.1090/noti976
What has been the impact of these reductions of revenue on jobs for doctorates in mathematics education in institutions of higher education? This study reports results from a survey of national searches by institutions of higher education for new faculty members in mathematics education.

\section{Survey Procedures}

Beginning in September 2011 and continuing to April 2012, announcements of job searches for tenure-track positions in mathematics education at institutions of higher education were compiled. Over one hundred institutions of higher education were initially identified as searching for at least one new tenure-track faculty member in mathematics education. Job announcements from

The senior author acknowledges IRD support from the National Science Foundation which allowed this work to be conducted. However, the content and opinions in this report are the authors' only and do not necessarily reflect any position of the NSF.

The authors gratefully acknowledge the chairs of the search committees of institutions for their willingness to take the time to complete the survey and contribute the information on which this report is based. 
institutions outside the U.S., and postdocs or nonregular appointments were eliminated. In April 2012, a personal email message was sent to the search chair at each institution on the remaining search list $(\mathrm{N}=104)$. Twelve respondents indicated that, due to budget reductions and some major policy changes, their search had been abandoned. The chairs of the search committees of the remaining ninety-two institutions were asked to complete an online survey on the status and success of their job searches. Subsequent emails to nonrespondents together with personal phone calls resulted in responses from eighty-two institutions (89 percent return rate).

\section{Job Expectations}

Over 90 percent of the positions announced were at the assistant professor level, with the others indicating their rank was open depending on the qualifications of the applicants. Teaching expectations for the posted positions were very similar to the profiles previously reported [3]. More specifically, the teaching responsibilities for faculty joining mathematics departments typically included teaching a range of undergraduate mathematics courses (e.g., content courses for future elementary/middle/secondary teachers, including calculus and linear algebra). Some institutions (about 40 percent) looked to these new hires to teach a wider array of upper-division mathematics courses, and a few (about 20 percent) expected the new hires to teach graduate courses in mathematics.

New faculty hires in departments/colleges of education were typically expected to teach undergraduate courses focusing on methods for teaching mathematics (elementary, middle, and secondary levels) and student-teaching supervision. The graduate teaching expectations in colleges/departments of education varied greatly and ranged from leading seminars on current issues to teaching specific courses, including curriculum, assessment, learning theory, technology, and research, each with a specific focus on mathematics education.

Research expectations varied greatly across institutions but tended to be closely aligned with the Carnegie Classification shown in Table 1. Thus, while some research was encouraged by baccalaureate and master's institutions hiring new faculty, their primary focus was on teaching, and this was reflected in teaching loads of 12 to 15 credit-hours per semester. Doctoral-granting institutions had lower teaching loads (typically 3-6 credit-hours per semester), along with a clearly stated priority for the applicant to establish a research agenda and develop a productive record of scholarship while working toward tenure and promotion.

Table 1. Number of positions (and hires) in mathematics education by type of Carnegie institution.

\begin{tabular}{|c|c|c|c|c|c|c|}
\hline Carnegie Classification & $\begin{array}{l}\text { Total \# of } \\
\text { positions }\end{array}$ & $\begin{array}{l}\text { Total \# of } \\
\text { institutions }\end{array}$ & $\begin{array}{c}\text { Math } \\
\text { Department }\end{array}$ & Education & Joint & $\begin{array}{c}\text { Percent of } \\
\text { successful } \\
\text { searches }\end{array}$ \\
\hline $\begin{array}{l}\text { Bac/Diverse: Baccalaureate } \\
\text { Colleges-diverse fields }\end{array}$ & 1 & 1 & $\begin{array}{c}1 \\
(0)\end{array}$ & & & 0 \\
\hline $\begin{array}{l}\text { Bac/A\&S: Baccalaureate Colleges- } \\
\text { Arts \& Sciences }\end{array}$ & 2 & 2 & $\begin{array}{c}1 \\
(0)\end{array}$ & $\begin{array}{c}1 \\
(0)\end{array}$ & & $50 \%$ \\
\hline $\begin{array}{l}\text { Master's S: Master's Colleges and } \\
\text { Universities (smaller programs) }\end{array}$ & 2 & 2 & $\begin{array}{c}2 \\
(2)\end{array}$ & & & $100 \%$ \\
\hline $\begin{array}{l}\text { Master's M: Master's Colleges and } \\
\text { Universities (medium programs) }\end{array}$ & 1 & 1 & $\begin{array}{c}1 \\
(0)\end{array}$ & & & 0 \\
\hline $\begin{array}{l}\text { Master's L: Master's Colleges and } \\
\text { Universities (larger programs) }\end{array}$ & 27 & 24 & $\begin{array}{c}22 \\
(16)\end{array}$ & $\begin{array}{c}5 \\
(5) \\
\end{array}$ & & $78 \%$ \\
\hline $\begin{array}{l}\text { DRU: Doctoral/Research } \\
\text { Universities }\end{array}$ & 5 & 4 & $\begin{array}{c}3 \\
(3)\end{array}$ & $\begin{array}{c}2 \\
(2)\end{array}$ & & $100 \%$ \\
\hline $\begin{array}{l}\text { RU/H: Research University (high } \\
\text { research activity) }\end{array}$ & 26 & 23 & $\begin{array}{c}8 \\
(6) \\
\end{array}$ & $\begin{array}{c}16 \\
(10) \\
\end{array}$ & $\begin{array}{c}2 \\
(1) \\
\end{array}$ & $65 \%$ \\
\hline $\begin{array}{l}\text { RU/VH: Research University (very } \\
\text { high research) }\end{array}$ & 22 & 17 & $\begin{array}{c}3 \\
(3) \\
\end{array}$ & $\begin{array}{c}17 \\
(16) \\
\end{array}$ & $\begin{array}{c}2 \\
(2)\end{array}$ & $95 \%$ \\
\hline Other unidentified institutions & 8 & 8 & $\begin{array}{c}3 \\
(2)\end{array}$ & $\begin{array}{c}5 \\
(5) \\
\end{array}$ & & \\
\hline Total & 94 & 82 & $\begin{array}{c}44 \\
(32)\end{array}$ & $\begin{array}{c}46 \\
(38)\end{array}$ & $\begin{array}{c}4 \\
(3)\end{array}$ & \\
\hline Percent of successful searches & & & $72 \%$ & $82 \%$ & $75 \%$ & $77 \%$ \\
\hline
\end{tabular}

Note: There were a total of 94 positions and 73 total hires. (n) reports the number of hires in each cell. 
Table 2. Percent of positions* reporting salaries within a range.

\begin{tabular}{|l|c|c|c|}
\hline $\begin{array}{l}\text { Salary Range } \\
\text { (US\$) }\end{array}$ & $\begin{array}{c}\text { Education } \\
\text { Department/ } \\
\text { College }\end{array}$ & $\begin{array}{c}\text { Mathematics } \\
\text { Department }\end{array}$ & $\begin{array}{c}\text { Joint } \\
\text { Appointment }\end{array}$ \\
\hline$\$ 40,000-50,000$ & 2 & 9 & 0 \\
\hline$\$ 50,001-60,000$ & 20 & 25 & 3 \\
\hline$\$ 60,001-70,000$ & 23 & 6 & 1 \\
\hline$\$ 70,001-80,000$ & 4 & 5 & 0 \\
\hline Above $\$ 80,000$ & 2 & 0 & \\
\hline
\end{tabular}

*Based on 84 responses to the salary range question.

\section{Information about the Job Opportunities and Success in Hiring}

Table 1 shows the Carnegie Classification of each of the eighty-two institutions ${ }^{1}$ included in the study. Their current classification was confirmed at http:// classifications.carnegiefoundation. org/lookup_listings/institution.php. The eighty-two searching institutions reported a total of 94 positions, and these positions were about equally distributed between mathematics departments (44), education (46), and joint appointments (4). Table 1 shows that nearly three-fourths (72 percent) of the positions in the mathematics departments and about 82 percent of the positions in education were filled. The baccalaureate- and master's-level institutions had the most difficulty in successfully making a hire.

The searches resulted in 73 hires, of which 65 had either a Ph.D. or Ed.D. in mathematics education, 6 had a Ph.D. in mathematics, and two had doctorates in other fields. In each case the institution hiring a Ph.D. in mathematics noted that their hire had either done some academic work in mathematics education or expressed a keen interest in mathematics education. Of the 73 hires reported, 37 were new doctorates in mathematics education and 36 were experienced faculty members moving from one institution to another. Thus nearly onehalf of the new hires were moving from one institution to another, thereby creating a new opening in mathematics education at the previous institution. This seemingly high rate of mobility among faculty members in mathematics education is consistent with results reported in 2006 [3].

\section{Salaries and Start-up Packages}

Respondents were asked, "What range best describes your projected salary for this position?" Table 2 summarizes the responses. The salary ranges of searches in mathematics and education departments/colleges are similar for several ranges but differ in the lowest range, where 9 percent

\footnotetext{
${ }^{1}$ Eight of the institutions did not include their name but completed the survey. Their Carnegie classification was not known, so their data are included in the "Other" category.
}

of the mathematics department positions were in the range of US\$40,000-\$50,000. Further examination revealed the institutions offering the lower salary range were in the Carnegie baccalaureate and master's classifications, and these institutions were least likely to make a hire, suggesting the importance of having a more competitive salary. The other discrepancy was in the salary range of US\$60,001-\$70,000, where the percent of positions in education (23 percent ) was nearly four times greater than in mathematics departments (6 percent).

Respondents were also asked, "What best describes the start-up package associated with your position?" The statement went on to say that a start-up package might include items such as a computer, software, travel, and moving expenses. Start-up packages ranged from none (about 6 percent of the positions) to more than US $\$ 20,000$ (provided for about 8 percent of the positions). About one-third of the institutions offered between US $\$ 1,000$ and US\$5,000, and about one-eighth of the institutions offered between US\$10,000 and US\$20,000 for start-up. There were no major differences between the positions in start-up packages between mathematics departments and education. In addition, a majority of institutions offered new faculty members a reduction in teaching load their first year.

\section{Some Implications}

This study documents that, while there is not the excess of jobs for doctorates in mathematics in institutions of higher education that there has been in the past [2], [3], there are still jobs for doctorates in mathematics education that were unfilled. This study showed that of the 70 percent of the institutions that began their job searches early in the fall, more than 25 percent filled their positions by December or January. Thus candidates interested in these positions are well advised to get their application papers ready early so they are prepared when job announcements are forthcoming. Institutions that wait until late in the academic year to announce a position in mathematics education are at a disadvantage, as many potential applicants have already been hired.

In addition to the unfilled positions for 2012-13, over 25 percent of the institutions indicated that they will be searching for another doctorate in mathematics education for 2013-14. So, even in the current austere financial environment, jobs in mathematics education exist. And when you consider the fact that about one-half of these announced positions were filled by mathematics educators moving from another institution, thereby creating another position, it is likely that the job opportunities within mathematics 
education for doctorates in mathematics education will remain strong.

In closing, it should be noted that this survey focused only on nationally announced job searches that were distributed in primary outlets. Many regional institutions do not conduct national searches, and this study does not reflect many regional postings. In fact, the majority of the positions identified in this study were in doctoralgranting institutions, even though there are many more baccalaureate or master's-level institutions. Furthermore, there were no associate degree awarding institutions, even though more than 1,700 junior colleges exist. So it is likely that this report significantly underestimates the number of jobs available in institutions of higher education for doctorates in mathematics education.

\section{References}

[1] J. Hiebert, J. Kilpatrick, and M. Lindquist (2001), Improving U.S. doctoral programs in mathematics education, In R. E. Reys and J. Kilpatrick (eds.), One Field, Many Paths: U. S. Doctoral Programs in Mathematics Education (pp. 153-162). Washington, DC: American Mathematical Society/Mathematical Association of America.

[2] R. E. Reys (2000), Doctorates in mathematics education: An acute shortage, Notices of the Amer. Math. Soc. 47, 1267-1270.

[3] ___ (2006), Jobs in mathematics education in institutions of higher education in the United States, Notices of the Amer. Math. Soc. 55, 676-680.
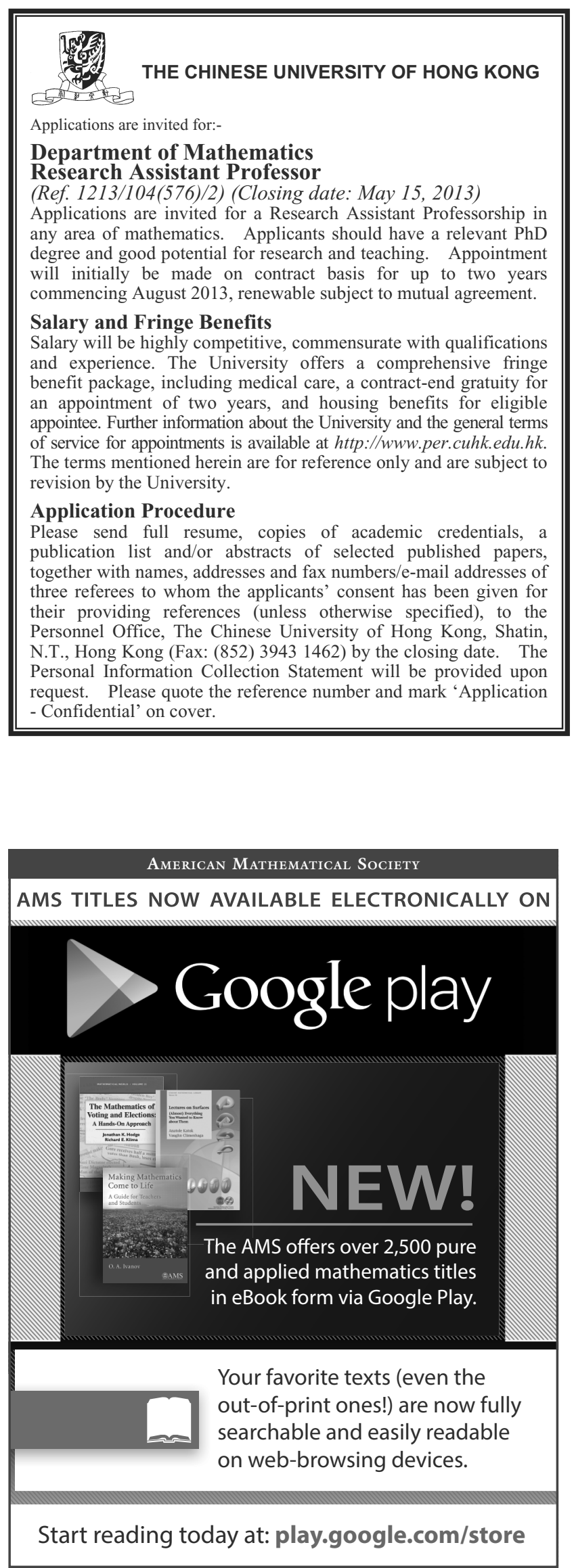